\title{
Determination of immune response of Newcastle disease virus vaccines in layer chickens
}

\author{
N. A. Banu, M. S. Islam, M. M. H. Chowdhury and M. A. Islam \\ Department of Microbiology and Hygiene, Bangladesh Agricultural University, Mymensingh-2202, Bangladesh
}

\begin{abstract}
The study was conducted for the detection of persistence of Maternally derived antibody (MDA) as well as the comparative evaluation of antibody production of nine different NDV vaccines in layer chickens in the Department of Microbiology and Hygiene, Bangladesh Agricultural University, Mymensingh during the period from July to December 2008. A total of 55 layer chicks (ISA Brown breed) were divided into eleven groups each consisting of five birds of which odd number groups were vaccinated primarily with Nobilis ${ }^{\circledR}$ MA5+Clone 30 , Avipro ${ }^{\circledR}$ ND-IB HB1, Cevac ${ }^{\circledR}$ BIL, Newcastle-Bronchitis Vaccine Fortdoge ${ }^{\circledR}$ and Avipro ${ }^{\circledR}$ ND LaSota vaccine respectively at day 5 of age and secondarily with Nobilis ${ }^{\circledR}$ ND Clone30, Avipro ${ }^{\circledR}$ ND LaSota, Cevac ${ }^{\circledR}$ New L, Newcastle Disease Vaccine Fortdoge ${ }^{\circledR}$ and Avipro ${ }^{\circledR}$ ND LaSota vaccine respectively at day 21 of age by single eye instillation and even number groups were vaccinated with the same vaccines respectively by double eye instillation following the same schedule. Again group 9 and group 10 were also vaccinated with RDV at 60 days of age through intramuscular route. Group 11 was kept as unvaccinated control. Sera samples were collected after 10 days of each vaccination and at day 5, 15, 20, 31 of age from unvaccinated control and subjected to $\mathrm{HI}$ test for the determination of antibody titres. It was observed that after primary vaccination the mean of $\mathrm{HI}$ titres of double eye vaccinated groups differed significantly $(P<0.01)$. Overall analysis of mean of $\mathrm{HI}$ titres of double eye vaccinated groups revealed that there were significant increases $(P<0.01)$ in $\mathrm{HI}$ titres in groups $8(891.44 \pm 228.97)$ and $10(861.66 \pm 140.21)$ compared to other groups. It was observed that secondary vaccination produced higher immune response compared to primary vaccination in case of all the vaccinated groups and double eye vaccination produced higher immune response compared to single eye vaccination in case of all the vaccinated groups. It was also observed that following vaccination with RDV in groups 9 and 10, $\mathrm{HI}$ titres increased significantly $(\mathrm{P}<0.01)$ which indicated that group $10(1204.30 \pm 280.43)$ produced significantly higher antibody titres than group $9(966.74 \pm 144)$. Maternal antibody was high (483.37 \pm 181.01$)$ at day 5 of age and persisted to a minimal level $(8.00 \pm 0.00)$ until the age of day 20 and almost disappears $(\leq 4 \pm 0)$ at day 31 of age. From the present research it may be concluded that LaSota strain produced higher immune response than Clone 30 and $B_{1}$ strain, Fortdose ${ }^{\circledR}$ and Avipro ${ }^{\circledR}$ vaccine produced higher immune response than all other vaccines and vaccination with lentogenic strains followed by mesogenic strain produced higher antibody titers used in this study.
\end{abstract}

Keywords: Immune response, Newcastle disease, Vaccines, Layer chickens

\section{Introduction}

Newcastle disease (ND) is a deadly viral disease of poultry all over the world since the time of first isolation in England in 1926 till today. It is also considered as one of the major economic threats to poultry population because of its high morbidity and mortality varies from $90-100 \%$ depending on the type of ND virus exposed (Brandly, 1950). It is an acute, contagious infection of pet, free living and domestic birds. Effective control of ND relies on the use of safe and good vaccines. Live vaccines prepared with lentogenic and mesogenic strain of NDV are now more commonly used in both broiler and layer birds. This is because live vaccines can be produced on a large scale at a relatively low cost. The vaccines are easy to administer on a large scale, and rapidly stimulate humoral, cell-mediated and mucosal surface immunity in the vaccinated birds. Vaccination as directed by Chowhdury et al. (1981) includes administration of live lentogenic vaccine (BCRDV) of F-strain by i/o inoculation to first week and 21 days old chicks followed by a live mesogenic vaccine (RDV) of Mukteswar strain by intramuscular route at day 60 and are repeated at every 6 months interval for the maintenance of sustainable level of neutralizing antibody in the serum of vaccinated birds. In Bangladesh, various live vaccines containing lentogenic strains of NDV such as $B_{1}$, Lasota, VG/GA, ND-clone are brought by several importer but efficacy of these vaccines in relation to climatic condition, distribution and transportation are not always investigated properly and thoroughly either by the importer or by the user. Sometimes, the farmers/ rearers are suspicious about the protective nature of those imported NDV vaccines. A number of relevant questions are faced by scientists and field Veterinarians of this country as to the immunogenicity, virus titre, stability and such other qualities of those vaccines. In order to address such query, the present study was undertaken to determine the persistence of maternally derived antibody in the layer chicks, to compare the antibody titres of chickens vaccinated with eight different imported vaccines of lentogenic strains of NDV and also to determine the antibody titres of chickens vaccinated with lentogenic and followed by mesogenic strain of NDV vaccines used in this study. 


\section{Materials and Methods}

The whole experiment was conducted during the period from July to December 2008 in the Department of Microbiology and Hygiene, Faculty of Veterinary Science, Bangladesh Agricultural University, Mymensingh.

\section{Experimental chickens}

A total number of 55 day-old-chicks of ISA Brown breed with the history of parent stock vaccinated against Newcastle disease (ND) were obtained with the curtesy of C.P. Bangladesh Co. Ltd., Dhaka and carried to the experimental animal shed of the Department of Microbiology and Hygiene, BAU, Mymensingh. The birds were reared in litter supplying Nurish ${ }^{\circledR}$ poultry feed and water maintaining strict bio-security. Before vaccination the birds were divided into 11 groups, each group consists of five birds. The chicks of group 11 were kept as unvaccinated control.

\section{Newcastle disease virus vaccines}

Nine lyophilized (freeze-dried) NDV vaccines were used in this study. These were (i) Nobilis ${ }^{\circledR}$ MA5+Clone 30 (Mass and clone 30 strain) of Intervet International (ii) Avipro ${ }^{\circledR}$ ND-IB HB1(Mass and B1 strain) of Lohmann Animal Health (iii) Cevac ${ }^{\circledR}$ BIL (Mass and B1 strain) of Ceva pharmaceuticals (iv) NewcastleBronchitis Vaccine Fortdoge ${ }^{\circledR}$ (Mass and B1 strain) of Fortdodge Animal Health (v) Nobilis ${ }^{\circledR}$ ND Clone30 (Clone 30 strain) of Intervet International (vi) Avipro ${ }^{\circledR}$ ND LaSota (LaSota strain) of Lohmann Animal Health (vii) Cevac ${ }^{\circledR}$ New L (LaSota strain) of Ceva pharmaceuticals (viii) Newcastle Disease Vaccine Fortdoge (LaSota strain) of Fortdodge Animal Health and (ix) RDV (M strain) of DLS. Vaccines were obtained with the courtesy of C.P. Bangladesh Co. Ltd. These vaccines were stored at $-20^{\circ} \mathrm{C}$ until used.

\section{Reference Newcastle disease virus}

Newcastle disease virus (Komarov strain) used in microplate $\mathrm{HI}$ test for the determination of antibody titre were collected from the laboratory repository of the Department of Microbiology and Hygiene, BAU, Mymensingh was propagated to activate the virus into 10- day- old embryonated chicken eggs through allantoic cavity route. AF was collected aseptically using sterile syring and needle transferred to sterile containers. The presence of NDV in AF was tested by slide HA test and those manifesting HA- positive were collected (Cottral, 1978) as a source of reference ND virus and stored at $-20^{\circ} \mathrm{C}$ until used.

\section{Vaccination schedule}

A total of 55 layer chicks (ISA Brown) were divided into eleven groups such as 1,2,3,4, 5, 6, 7, 8, 9, 10 and 11 where each group consisting of five birds. Group 1, 3, 5.7 and 9 were primarily vaccinated with Nobilis ${ }^{\circledR}$ MA5+Clone 30, Avipro ${ }^{\circledR}$ ND-IB HB1, Cevac ${ }^{\circledR}$ BIL, Newcastle-Bronchitis Vaccine Fortdoge ${ }^{\circledR}$ and Avipro $^{\circledR}$ ND LaSota vaccine respectively at day 5 of age and secondarily with Nobilis ${ }^{\circledR}$ ND Clone30, Avipro ND LaSota, Cevac ${ }^{\circledR}$ New L, Newcastle Disease Vaccine Fortdoge ${ }^{\circledR}$ and Avipro ${ }^{\circledR}$ ND LaSota vaccine respectively at day 21 of age by single eye instillation and $2,4,6,8$ and 10 were vaccinated with the same vaccines respectively by double eye instillation following the same schedule. Again group 9 and group 10 were also vaccinated with RDV at 60 days of age through intramuscular route. Group 11 was kept as unvaccinated control. Sera samples were collected after 10 days of each vaccination and at day $5,15,20,31$ of age from unvaccinated control and subjected to $\mathrm{HI}$ test for the determination of antibody titres.

\section{Microlplate heamagglutination inhinition $(\mathrm{HI})$ test}

Micro-plate $\mathrm{HI}$ test was performed (Anon, 1971) to determine the antibody level of the sera samples collected from the chicks of different groups. The test was conducted using constant 4HA unit ND virus and diluted serum ( $\beta$ method).

\section{Statistical analysis}

Statistical Package for social Sciences (SPSS) version 10.0 programme was used to analyze the data of the study. ANOVA Duncan's Multiple Range Test (DMRT) and Paired ' $t$ ' test were performed to determine the significant differences in $\mathrm{HI}$ titres of chickens of a group after primary and secondary vaccination (Beri, 2005). 


\section{Results and Discussion}

Maternally derived antibody (MDA) was measured on a number of occasions starting from day 5 to day 31 and the titres are presented in Table1. It was found that the MDA level persisted at a suitable lavel upto 15 days and it started to decline after 15 days and reached at a negligible label after 20 days. This findings strongly supports the findings of Shil 2006; Balla 1986; Saeed et al., 1988, Chowdhury et al., 1982 and Islam et al., 2003 who stated that the persistence of MDA in chickens were day 15 to 20 of age. But Mahud et al., 2007 reported that the persistence of MDA upto 27 days of age which may be due to the high MDA titres.

Table 1. Maternal antibody of unvaccinated control of layer chickens (ISA Brown) determined by HI test

\begin{tabular}{|c|c|c|c|c|c|c|c|c|}
\hline \multirow{3}{*}{$\begin{array}{l}\text { No. of } \\
\text { serum } \\
\text { sample }\end{array}$} & \multicolumn{8}{|c|}{ Age of birds } \\
\hline & \multicolumn{2}{|r|}{ Day 5} & \multicolumn{2}{|c|}{ Day 15} & \multicolumn{2}{|c|}{ Day 20} & \multicolumn{2}{|c|}{ Day 31} \\
\hline & Titre & $\begin{array}{c}\text { Mean } \pm \text { SD } \\
(n=5)\end{array}$ & Titre & $\begin{array}{c}\text { Mean } \pm \text { SD } \\
(n=5)\end{array}$ & Titre & $\begin{array}{c}\text { Mean } \pm \text { SD } \\
(n=5)\end{array}$ & Titre & $\begin{array}{c}\text { Mean } \pm \text { SD } \\
(n=5)\end{array}$ \\
\hline 1 & 512 & \multirow{5}{*}{$602.15 \pm 140.21$} & 96 & \multirow{5}{*}{$75.26 \pm 17.25$} & 8 & \multirow{5}{*}{$8.00 \pm 0.00$} & $\leq 4$ & \multirow{5}{*}{$\leq 4 \pm 0$} \\
\hline 2 & 512 & & 96 & & 8 & & $\leq 4$ & \\
\hline 3 & 768 & & 64 & & 8 & & $\leq 4$ & \\
\hline 4 & 768 & & 64 & & 8 & & $\leq 4$ & \\
\hline 5 & 512 & & 64 & & 8 & & $\leq 4$ & \\
\hline
\end{tabular}

$\mathrm{n}=$ Number of sera samples tested.

$\mathrm{SD}=$ Standard deviation

$\mathrm{HI}=$ Haemagglutination inhibition.

The principal objective of this study was to observe the immune response of live NDV vaccines (both lentogenic and mesogenic strain) in layer chickens commonly used in Bangladesh. It was observed that the mean and Standard deviation of $\mathrm{HI}$ titres after primary vaccination by single eye instillation in groups $1,3,5,7$ and 9 were $691.69 \pm 214.18,187.52 \pm 45.25,388.02 \pm 140.21,483.37 \pm 57.24$ and $375.05 \pm$ 90.50 respectively and after 10 days of secondary vaccination $345.84 \pm 107.09,483.37 \pm 57.24,555.24 \pm$ $114.48,602.15 \pm 114.21$ and $841.60 \pm 228.97$ respectively whereas birds of double eye instillation vaccinated groups $2,4,6,8$ and 10 the mean of the titres were $794.52 \pm 214.18,345.84 \pm 107.09 .354 .08$ $\pm 57.24,555.24 \pm 114.48$ and $337.79 \pm 140.21$ respectively and after 10 days of secondary vaccination $397.27 \pm 107.9,794.54 \pm 214.18,813 \pm 114.48,891.44 \pm 228.97$ and $861.66 \pm 140.21$ respectively (Table 2).

It was observed that double eyes vaccinated groups of layer chickens produced significantly $(\mathrm{P}<0.01)$ higher immune response compare to those of single eye vaccinated chickens. This increase immune response may be due to the amount of virus present in each dose. The vaccine virus concentration is higher in double eye dose than to the single eye dose which played a vital role in the production of high immune response. For better immune response the dose of vaccine was important factor which helps to increase in the level of antibody production which is closely related to the finding of Bankowski and Hill, 1954 and Winterfield and Seadle, 1957.

After secondary vaccination it was also observed that the antibody titres increased in all groups except group $1 \& 2$ where the antibody level declined. So, cloned 30 might not immunogenic than other strains (B and LaSota strains). Kafi et al. (2003) found the highest $\mathrm{HI}$ titres after secondary vaccination with BCRDV. Shuaib et al. 2003) reported that secondary vaccination yielded HI titres that was significantly higher than the $\mathrm{HI}$ titres after single vaccination.

A comparative analysis of all the vaccines of different strains revealed that LaSota strain produced higher immune response than those of other strains- $B_{1}$ and Clone 30 strain. This finding is strongly supported to the findings of Almassy et al. (1979) and Mallick et al. (1969) who reported that LaSota strain provided superior antibody production after vaccination compared to B1. Westbury et al. 1984) also observed that LaSota is much more immunogenic than the Hitchner B1. However, Ibrahim (1983) did not find any significant difference in immunizing capacity, protection and stress between $\mathrm{F}$ strain and $\mathrm{B}_{1}$ strain. 
Table 2. Comparative $\mathrm{HI}$ titres of chickens between single and double eyes vaccination with different NDV vaccines

\begin{tabular}{|c|c|c|c|c|c|c|}
\hline \multirow[b]{2}{*}{ Groups } & \multicolumn{2}{|c|}{ Vaccines used } & \multirow{2}{*}{$\begin{array}{l}\text { Dose and } \\
\text { route of } \\
\text { vaccination }\end{array}$} & \multicolumn{2}{|c|}{$\begin{array}{l}\text { Serum HI titre (Mean } \pm \text { SD) } \\
\qquad(n=5)\end{array}$} & \multirow{2}{*}{$\begin{array}{l}\text { Level of } \\
\text { significance }\end{array}$} \\
\hline & $\begin{array}{c}\text { Primary } \\
\text { vaccination }\end{array}$ & $\begin{array}{l}\text { Secondary } \\
\text { vaccination }\end{array}$ & & $\begin{array}{l}\text { Post-primary } \\
\text { vaccination }^{A} \\
\text { (15 days old })\end{array}$ & $\begin{array}{c}\text { Post-secondary } \\
\text { vaccination }^{B} \\
\text { (31 days old) }\end{array}$ & \\
\hline 1 & \multirow{2}{*}{$\begin{array}{l}\text { Nobilis }^{\circledR} \\
\text { MA5+Clone30 }\end{array}$} & \multirow{2}{*}{$\begin{array}{l}\text { Nobilis }{ }^{\circledR} \mathrm{ND} \\
\text { Clone30 }\end{array}$} & $\begin{array}{c}\text { One drop in } \\
\text { one eye }\end{array}$ & $691.69 \pm 214.18$ & $345.84 \pm 107.09$ & $B$ \\
\hline 2 & & & $\begin{array}{c}\text { One drop in } \\
\text { two eyes }\end{array}$ & $794.54 \pm 214.18$ & $397.27 \pm 107.09$ & B \\
\hline 3 & \multirow{2}{*}{$\begin{array}{l}\text { Avipro }{ }^{\circledR} \mathrm{ND}-\mathrm{IB} \\
\mathrm{HB} 1\end{array}$} & \multirow{2}{*}{$\begin{array}{l}\text { Avipro }{ }^{\circledR} \mathrm{ND} \\
\text { LaSota }\end{array}$} & $\begin{array}{l}\text { One drop in } \\
\text { one eye }\end{array}$ & $187.52 \pm 45.25$ & $483.37 \pm 57.24$ & $\mathrm{C}$ \\
\hline 4 & & & $\begin{array}{l}\text { One drop in } \\
\text { two eyes }\end{array}$ & $345.84 \pm 107.09$ & $794.54 \pm 214.18$ & $\mathrm{~B}$ \\
\hline 5 & \multirow{2}{*}{$\operatorname{Cevac}^{\circledR}$ BIL } & \multirow{2}{*}{$\operatorname{Cevac}^{\circledR}$ New L } & $\begin{array}{l}\text { One drop in } \\
\text { one eye }\end{array}$ & $388.02 \pm 140.21$ & $555.24 \pm 114.48$ & $\mathrm{~B}$ \\
\hline 6 & & & $\begin{array}{c}\text { One drop in } \\
\text { two eyes }\end{array}$ & $354.08 \pm 57.24$ & $813 \pm 114.48$ & $\mathrm{~B}$ \\
\hline 7 & \multirow{2}{*}{$\begin{array}{l}\text { Newcastle- } \\
\text { Bronchitis } \\
\text { Vaccine } \\
\text { Fortdodge }^{\circledR}\end{array}$} & \multirow{2}{*}{$\begin{array}{l}\text { Newcastle } \\
\text { Disease } \\
\text { Vaccine } \\
\text { Fortdodge }^{\circledR}\end{array}$} & $\begin{array}{l}\text { One drop in } \\
\text { one eye }\end{array}$ & $483.37 \pm 57.24$ & $602.15 \pm 140.21$ & B \\
\hline 8 & & & $\begin{array}{l}\text { One drop in } \\
\text { two eyes }\end{array}$ & $555.24 \pm 114.48$ & $891.44 \pm 228.97$ & $A$ \\
\hline 9 & \multirow{2}{*}{$\begin{array}{l}\text { Avipro }{ }^{\circledR} \mathrm{ND} \\
\text { LaSota }\end{array}$} & \multirow{2}{*}{$\begin{array}{l}\text { Avipro }{ }^{\circledR} \mathrm{ND} \\
\text { LaSota }\end{array}$} & $\begin{array}{c}\text { One drop in } \\
\text { one eye }\end{array}$ & $375.05 \pm 90.50$ & $841.60 \pm 228.97$ & $A B$ \\
\hline 10 & & & $\begin{array}{l}\text { One drop in } \\
\text { two eyes }\end{array}$ & $337.79 \pm 140.21$ & $861.66 \pm 140.21$ & $A$ \\
\hline
\end{tabular}

$\mathrm{n}=$ Number of sera samples tested.

A Primary vaccination of all the groups was done at 5 days old.

${ }^{B}$ Secondary vaccination of all the groups was done at 21 days old.

Figures with different letter within column 7 differ significantly $(P<0.01)$.

$\mathrm{SD}=$ Standard deviation

$\mathrm{HI}=$ Haemagglutination inhibition.

Birds of all vaccinated groups did not respond equally to vaccination in the same manner and individual variation in the humoral immune response was observed within the same group of birds at the same interval following both primary and secondary vaccination, which corresponds with the findings of Saifuddin et al. (1986). The variation also might be due to the presence of variable MDA in chicks or varying degree of susceptibility of immune mechanism to antigen as observed by Toth and Markovits (1964).

Overall consideration among the vaccinated groups it was observed that the $\mathrm{HI}$ titres of birds of groups vaccinated primarily with Newcastle-Bronchitis Vaccine Fortdodge ${ }^{\circledR}$ and secondarily with Newcastle Disease Vaccine Fortdodge ${ }^{\circledR}$ by double eyes dose and group 10 vaccinated primarily and secondarily with Aviproß ND LaSota by double eye dose produced higher immune response than all other vaccinated groups.

The present study also revealed that groups 9 and 10 after third vaccination with RDV (M-strain) at 60 days of age through intramuscular route showed significantly $(P<0.01)$ higher immune response, which is closely related to the finding of Chowdhury et al. (1981). However Kafi et al. (2003) reported that administration of live lentogenic vaccine followed by inactivated killed vaccine would produced durable immunity. 


\section{Acknowledgement}

The authors are thankful to CP Bangladesh Co Ltd. for financial help for the study.

\section{References}

Alexander, D.J. 1991. Newcastle disease and other paramyxovirus infections. In: Diseases of poultry. $9^{\text {th }}$ edition, edited by B.W. Calnek, H.J. Barnes, C.W. Beard, W.M. Reid and H.W. Jorder Jr. Ames, lowa, U.S.A: lowa State University Press: pp. 496-519.

Alexander, D.J. 1997. Newcastle disease and other avian Paramyxoviridae infections. In: Diseases of Poultry $10^{\text {th }}$ edition, edited by B.W. Calnek, H.J. Barnes, C.W. Beard, L.R. McDougald \& Y.M. Saif. Ames, lowa, U.S.A: lowa state University press: pp. 541-569.

Almassy, K., Barhouma, N., El-sabbagh, A., Ibrahim, S.N. Boktor, N., Khashaba, E. and Gawad, S.A. 1979. Comparative immunization experiments with lentogenic Newcastle disease vaccine strain. J. Egypt Vet. Med. Asso. 35: 95-104.

Anon, 1971. Methods for examining poultry biologies and for identification and quantifying avian pathogens. Newcastle disease, p.66. National Academy of sciences, Wasinghton, D.C.

Asplin, F.D. 1952. Immunigation against Newcastle disease with a virus of low virulence ( strain ) and observation of subclinical infection in partial resistant fowls. Veterinary records $64: 245-49$

Balla, L. 1986. Use of a standardized HI test for monitoring immunity to Newcastle disease. I. Experiments to standardize the HI test II. Antibody response after different immunization schedules. Magyar Allatorvoso Lapja. 41: 98-109.

Bankowsli, R.A and Hill, R.W. 1954. Factors influencing the efficiency of vaccination by the air borne route. Proc $91^{\text {st }}$ Ann. Meet. American Vet. Med. Assoc. Sca. PP. 317-327.

Barbezange, C. and Jestin, V. 2005. Molecular study of the quasispecies evolution of a typical pigeon paramyxovirus type 1 after serial passages in pigeons by contact. Avi. Path. $34: 111$ - 122.

Beri, G.C. 2005. Business Statistics, $2^{\text {th }}$ edition, Tata Mc Graw-Hill publishing company limited, New Delhi, India.

Brandly, C.A. 1950. Newcastle disease. Am. J. Vet. Res. 116: 139.

Chowdhury, S.I., Chowdhury, T.I.M.F.R., Sarker, A.J. and Amin, M.M. 1981. Determination of an optimum age for primary Newcastle disease vaccination of chicks having maternal antibody. Bang. Vet. J. 15(1-2): 19 -17.

Chowdhury, T.I.M.F.R., Sarker, A.J., Amin, M.M. and Hossain, W.I.M.A. 1982. Studies on Newcastle disease in Bangladesh. A Research Report, Sec 2. The role of residual maternal antibody on immune response and selection of an optimum age for primary vaccination of chicks, pp. 12 - 20.

Cottral, G.E. 1978. Manual of standardized methods for veterinary microbiology .Cornell University press. Ithaca, N.Y. pp 47-52.

Hitchner, S.B. and Johnson, E.P. 1948. A virus of low virulence for immunizing fowls against Newcastle disease (Avian Pneumoencephalitis). Vet. Med. 43 (12): 525-530.

Ibrahim, A.L., Lai, M.C. and Aini, I. 1983. Spray vaccination with an improved F Newcastle disease vaccine.a comparison of efficacy with the BI and LaSota vaccines. Bri. Vet. J. 139: 213-219.

Islam, M.R. Huque, Q.M.L., Giasuddin, M.J. and Rahman, M.M. 2003. Assessment of maternally derived antibody of commercial flock against Newcastle disease. Proceedings of $3^{\text {rd }}$ international poultry show and seminar, Bangladesh china friendship conference center, Dhaka, Bangladesh $28^{\text {th }}$ February-2nd March 2003.

Kafi, M.A., Rahman, M.B., Amin, M.M., Islam, M.R., Rahman, M.M. and Rahman, M.K. 2003. Comparative serological responses and protection conferred by vaccination with V4HR and BCRDV in chicken. Bang. J. Vet. Med. 1(1): 25-27.

Mahmud, M.S., Hossain, M.T., Monoura, P. and Amin, M.M. 2007. Comparative efficacy of Avinew (VG/GA strain) and BCRDV (F strain) vaccines against Newcastle disease in broiler chickens. Bang. J. Vet. Med. 5(1\&2): 19-23

Mallick, B.B., Kapoor, K.N. and Chattopadhyaya, S.J. 1969. Some observations on vaccination against Newcastle disease. Ind. Vet. J. 46: 938 - 943.

Mayo, M.A. 2002. A summary of the changes recently approved by ICTV. Arch. Virol. 147: 1655 - 1656.

Saeed, Z., Ahmad, S., Rizvi, A.R. and Ajmal, M. 1988. Role of maternal antibody in determination of an effective Newcastle disease vaccination programme. Pak. J. Vet. Res. 1: 18-21.

Saifuddin, M., Sarker, A.J., Amin, M.M. and Rahman, M.A. 1986. Studies on the efficiency of Newcastle disease vaccines and their vaccination Schedule. Bang. Vet. J. 20(3): 67 - 74. 
Shil, N.C., Amin, M.M. and Rahman, M.B. 2006. Evaluation of antibody production following single vaccination with BCRDV, Izovac $B_{1}$ Hitchner and Cevac New L in broiler chicks. M.S. Thesis submitted to the department of Microbiology and Hygiene, Faculty of Vet. Science, BAU, Mymensingh.

Shuaib, M., Ashfaque, M., Sajjad-ur, R., Mansoor, M.K. and Yousaf, I. 2003. Comparative immune response of broiler chicks to Newcastle disease vaccine (LaSota strain). Pak. Vet. J. 23: 91-93.

Toth, B. and Markovits, P. 1964. Studies on the immunogenicity of Newcastle disease vaccine strains in growing chickens. Act. Vet. Hung. 14: 339-3345.

Westbury, H.A. 1984. Comparison of the immnnogenicity fo Newcastle Disease Virus strains $\mathrm{V}_{4} \mathrm{~B}_{1}$ and LaSota in chickens. Aus. Vet. J. $61: 5-9$.

WinterfieLd, R.W., Goldman, C.L. and Seadale, E.H. 1957. The immune response of chickens vaccinated at early age with B1 Newcastle disease virus administered through the drinking water under field condition. Poult. Sci 36: 107-88. 